\title{
PENGARUH KEBIJAKAN HUTANG DAN KEPUTUSAN INVESTASI TERHADAP NILAI PERUSAHAAN PADA PT. ARWANA CITRAMULIA TBK PERIODE 2010-2019
}

\author{
Sri Mardiana1, Iriana Kusuma Dewi² \\ Fakultas Ekonomi, Universitas Pamulang \\ Email: dosen02065@unpam.ac.id ${ }^{1}$,dosen01729@unpam.ac.id ${ }^{2}$
}

\begin{abstract}
Purpose. The objective of this study is to examine the influence of the Debt Policy and the Invesment Decision towards the Value of the Company in Arwana Citramulia Tbk Company during periode of year 2010/2019.

Methods. The method used of this study is quantitative data, sample used is financial statement in Arwana Citramulia, Tbk Company periode of year 2010/2019. Data analysis method using classical assumption test, simple regression, multiple linier, and statistical testing (partial test, simultaneous test and coefficient of determination).

Findings. The result shows that the Debt Policy and the Invesment Decision has not influence significanly towards the Value of the Company, but the Debt Policy and the Invesment Decision has same influence towards the Value of the Company in Arwana Citramulya, Tbk Company by the result is the value of Fcount < value of Ftable is $4.834>4,66$ or Fcount 4.834 $>$ F table 4,66 and sig. $<0.05$ is 0,048 $<0,05$.
\end{abstract}

Implication. Investors are advised to conduct analysis first before investing in a company to reduce the risk of loss, and investors must be able to know how the growth of investment in a company is.

Keywords. Debt Policy, Investment Decisions, and Company Value

\begin{abstract}
ABSTRAK
Tujuan. Penelitian ini bertujuan untuk mengetahui pengaruh Kebijakan Hutang dan Keputusan Investasi terhadap Nilai Perusahaan pada PT. Arwana Citramulia Tbk periode tahun 2010-2019.

Metode. Metode penelitian yang digunakan dalam penelitian adalah data yang bersifat kuantitatif. Sampel yang digunakan adalah berupa laporan keuangan pada PT. Arwana Citramulia, Tbk periode tahun 2010 - 2019. Metode analisis data menggunakan Uji asumsi klasik, regresi sederhana, linier berganda, serta pengujian statistic (uji parsial, uji simultan, dan koef. determinasi).

Hasil. Hasil analisis pengaruh Kebijakan Hutang dan Keputusan Investasi terhadap Nilai Perusahaan menunjukkan hasil perhitungan nilai signifikasi lebih besar dari 0,05 atau $0,091>0,05$ untuk variabel Kebijakan Hutang \& nilai signifikasi lebih besar dari 0,05 atau $0,624>0,05$ untuk variabel Keputusan Investasi. Hasil ini berarti kebijakan hutang dan keputusan investasi tidak berpengaruh secara signifikan terhadap nilai perusahaan, tetapi kebijakan hutang dan keputusan investasi secara bersama-sama berpengaruh terhadap nilai perusahaan pada PT. Arwana Citramulia, Tbk dengan hasil perhitungan nilai Fhitung $>$ nilai Ftabel yaitu sebesar $4.834>4.66$ atau Fhitung $4.834>$ Ftabel 4,66. lalu kemudian untuk sig. $<0.05$ yaitu $0.048<0.05$.
\end{abstract}


Implikasi. Bagi investor disarankan untuk melakukan analisis terlebih dahulu sebelum melakukan investasi pada sebuah perusahaan untuk mengurangi resiko kerugian, serta investor harus bisa mengetahui bagaimana pertumbuhan investasi pada sebuah perusahaan.

Kata Kunci. Kebijakan Hutang, Keputusan Investasi, dan Nilai Perusahaan

\section{Pendahuluan}

Dalam era globalisasi sekarang ini dunia usaha merupakan pemegang peranan penting, dalam bidang pembangunan. Banyak perusahaan yang berlomba-lomba meningkatkan kualitas perusahaannya agar mampu bersaing dalam pasar global dan menarik minat calon konsumen. Tujuan utama berdirinya sebuah perusahaan yaitu untuk meningkatkan laba atau keuntungan yang besar dan perusahaan yang telah go public selalu berusaha meningkatkan kemakmuran pemilik atau para pemegang saham melalui peningkatan nilai perusahaan. Nilai perusahaan dipengaruhi oleh beberapa faktor, antara lain faktor kebijakan hutang dan keputusan investasi. Kebijakan hutang merupakan kebijakan perusahaan tentang seberapa jauh perusahaan menggunakan hutang sebagai sumber pendanaannya. Penggunaan kebijakan hutang dapat digunakan untuk menciptakan nilai perusahaan yang diinginkan, tetapi apabila tingkat hutang melampaui proporsi hutang yang ditetapkan oleh perusahaan maka yang terjadi adalah penurunan nilai perusahaan. Keputusan investasi merupakan suatu kebijakan perusahaan dalam menginvestasikan dana yang dimiliki perusahaan dalam bentuk aset tertentu. Perusahaan yang memiliki keputusan investasi yang tinggi akan mampu mempengaruhi pemahaman investor terhadap perusahaan, sehingga dapat meningkatkan permintaan terhadap saham perusahaan. Dengan demikian, semakin tinggi minat investor dalam berinvestasi pada perusahaan maka keputusan investasi akan berdampak pada peningkatan nilai perusahaan.

Mengenai masalah kebijakan hutang dan keputusan investasi, dalam hal ini sangat berkaitan dengan perusahaan manufaktur karena perusahaan manufaktur mencerminkan pertumbuhan dan perkembangan ekonomi dan bisnis nasional, di samping itu juga merupakan sektor yang memiliki kompleksitas bisnis yang tinggi. Perusahaan manufaktur merupakan perusahaan yang kegiatannya membeli bahan baku kemudian mengolah bahan baku dengan mengeluarkan biaya-biaya lain menjadi barang jadi yang siap untuk dijual. Salah satu dari beberapa perusahaan manufaktur di Indonesia adalah perusahaan yang bergerak dalam bidang industri keramik yaitu PT. Arwana Citramulia, Tbk. Pada tahun 2005, PT. Arwana Citramulia, Tbk menjadi perusahaan yang go public dengan pembukaan harga saham Rp. $400 /$ lembar. Dalam upaya persaingan perusahaan di dunia industri keramik, PT. Arwana Citramulia terus berusaha untuk melakukan peningkatan dasar perusahaan terutama dalam mendukung kegiatan operasionalnya, seperti aktiva, hutang dan modal seperti berikut :

Tabel 1. Harga Saham, Hutang, dan Modal pada PT. Arwana Citramulia Tbk. Tahun 2010-2019 (dalam rupiah)

\begin{tabular}{|c|c|c|r|}
\hline Tahun & Harga Saham & Total Hutang & \multicolumn{1}{c|}{ Total Modal } \\
\hline 2010 & 72 & 458.094 .139 .651 & 415.059 .946 .271 \\
\hline 2011 & 91 & 348.334 .308 .520 & 483.173 .285 .156 \\
\hline 2012 & 408 & 332.551 .590 .871 & 604.808 .179 .406 \\
\hline 2013 & 820 & 366.754 .918 .531 & 768.489 .883 .529 \\
\hline 2014 & 870 & 346.944 .901 .743 & 912.230 .541 .132 \\
\hline 2015 & 489 & 536.050 .998 .398 & 894.728 .477 .056 \\
\hline 2016 & 580 & 595.128 .097 .887 & 948.088 .201 .259 \\
\hline 2017 & 363 & 571.946 .769 .034 & 1.029 .399 .792 .539 \\
\hline 2018 & 425 & 556.309 .556 .626 & 1.096 .596 .429 .104 \\
\hline 2019 & 451 & 622.355 .306 .743 & 1.176 .781 .762 .600 \\
\hline
\end{tabular}

Sumber : data diolah (2020) 
Berdasarkan tabel diatas dapat dilihat harga saham, total hutang dan modal yang selalu berfluktuasi setiap tahunnya. Harga saham tercatat mengalamin kenaikan dari tahun 20102014, kemudian mengalami penurunan pada tahun 2015 dan 2016, kemudian pada tahun tahun berikutnya selalu mengalami kenaikan.

Kemudian untuk total hutangnya terjadi pola yang sama yaitu setiap 3 tahun selalu mengalami kenaikan setelah sebelumnya mengalami penurunan seperti pada tahun 2011 dan 2012 mengalami penurunan untuk kemudian pada tahun berikutnya tahun 2013 mengalami kenaikan dan seterusnya kembali mengalami penurunan pada tahun 2014 dan 2015 kemudian terjadi kenaikan kembali pada tahun 2016, pola yang sama terjadi pada tahun berikutnya tahun 2017 dan 2018 terjadi penurunan kemudian di periode tahun 2019 terjadi kenaikan.

Total modal sendiri sepanjang tahun 2010 - 2014 selalu mengalami kenaikan yang kemudian pada tahun 2015 mengalami penurunan lalu kembali stabil mengalami kenaikan pada tahun $2016-2019$.

PT. Arwana Citramulia Tbk. sendiri tidak asing bagi penulis, karena penulis sudah menjadi bagian dari perusahaan ini sejak tahun 2017 hingga sekarang, kemudian penulis ingin memberikan kontribusi bagi perusahaan sebagai pertimbangan untuk memajukan perusahaan khususnya pada kebijakan hutang dan keputusan investasi perusahaan yang berdampak pada nilai perusahaan itu sendiri. Oleh sebab itu penelitian ini dilakukan untuk meneliti lebih lanjut mengenai "Pengaruh Kebijakan Hutang dan Keputusan Investasi Terhadap Nilai Perusahaan Pada PT. Arwana Citramulia Tbk Periode 2010-2019".

\section{Kajian Pustaka dan Hipotesis}

Kebijakan hutang. Menurut Sarah Usman (2017) Hutang adalah kewajiban suatu perusahaan yang timbul dari transasksi pada waktu lampau yang telah berlalu yang harus dibayarkan dengan menggunakan kas, barang atau jasa di masa yang akan datang. Transaksi tersebut baik terjadi secara sengaja atau direncanakan ataupun tidak direncanakan. Dengan cara seperti ini, perusahaan dapat mendanai kegiatan operasionalnya dengan cara memperoleh mesin, peralatan bahan baku, tenaga ataupun material terlebih dahulu yang kemudian digunakan untuk menunjang kegiatan operasionalnya.

$\mathbf{H}_{1}$. Kebijakan hutang berpengaruh signifikan terhadap nilai perusahaan.

Keputusan Investasi. Menurut Andewi Rokhmawati (2016) Keputusan investasi yaitu keputusan tentang akan digunakan untuk apa dana yang diperoleh atau dimiliki perusahaan. Investasi ini bisa berupa investasi jangka pendek (sering disebut sebagai working capital atau modal kerja), maupun investasi jangka panjang (sering disebut sebagai capital investment atau investasi modal).

$\mathbf{H}_{2}$. keputusan investasi berpengaruh terhadap nilai perusahaan.

Nilai Perusahaan. Menurut Renu Diah (2013) Nilai perusahaan adalah nilai jual perusahaan atau nilai tambah bagi pemegang sahamnya. Nilai perusahaan merupakan persepsi investor terhadap tingkat keberhasilan perusahaan yang sering dikaitkan dengan harga saham. Harga saham yang tinggi membuat nilai perusahaan juga tinggi. Nilai perusahaan yang tinggi akan membuat pasar percaya tidak hanya pada kinerja perusahaan saat ini, namun juga pada prospek perusahaan di masa depan.

$\mathbf{H}_{3}$. kebijakan hutang dan keputusan investasi berpengaruh secara signifikan terhadap nilai perusahaan. 


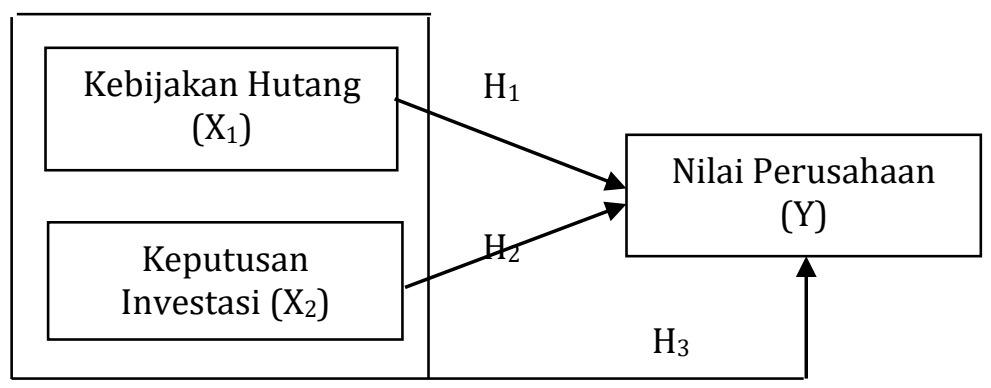

Gambar 1. Model Penelitian

\section{Metode Penelitian}

Jenis penelitian ini adalah deskriptif kuantitatif, yaitu melakukan pembahasan atas permasalahan yang dihadapi perusahaan terhadap kinerja perusahaan dari segi keuangan, data-data analisa yang digunakan adalah data yang bersifat kuantitatif yaitu data-data yang bersifat angka-angka. Dalam penelitian populasinya adalah laporan keuangan PT. Arwana Citramulia Tbk. Sementara sampel yang digunakan adalah laporan neraca dan laporan laba rugi PT. Arwana Citramulia Tbk periode 2010-2019.

\section{Analisis Deskriptif}

Menurut Sugiyono (2015:147) "Analisis deskriptif digunakan untuk menganilisis data dengan cara mendeskripsikan atau mengambar data yang terkumpul". Statistik deskriptif memberikan gambaran atau data yang dilihat dari rata-rata (mean), standar deviasi, varian, maksimum, minimum, sum, range, kurtosis dan Skewness (kemencangan distribusi).

\section{Uji Asumsi Klasik}

Uji asumsi klasik digunakan untuk mengetahui ketepatan sebuah data. Menurut Santoso (2015:342) berpendapat "Sebuah model regresi akan digunakan untuk melakukan peramalan sebuah model yang baik adalah model dengan kesalahan peramalan yang seminimal mungkin. Karena itu, sebuah model sebelum digunakan seharusnya memenuhi beberapa asumsi, yang biasa disebut asumsi klasik". Dalam penelitian ini uji asumsi klasik yang digunakan: Uji Normalitas, Uji Multikolinearitas, Uji Autokorelasi, dan Uji Heterokedastisitas.

\section{Analisis Kuantitatif}

Analisis kuantitatif adalah penelitian untuk menilai kondisi dari nilai pengaruh, dan signifikansi pengaruh tersebut. Dalam penelitian ini analisis kuantitatif yang digunakan: Analisis Regresi Linier Sederhana, Linier Berganda, Uji Parsial (Uji-t), Uji-F, dan Koefisien Determinasi.

\section{Hasil Penelitian dan Pembahasan Analisis Deskriptif}

Analisis desktiptif digunakan untuk menjawab rumusan masalah yaitu untuk mengetahui perkembangan keputusan investasi, kebiajakan hutang, dan nilai perusahaan dengan cara melihat perkembangan dari tahun ke tahun, lalu diuraikan ke dalam tabel berikut ini: 
Tabel 2. Hasil Uji Analisis Deskriptif

Descriptive Statistics

\begin{tabular}{|l|r|r|r|r|r|}
\hline & \multicolumn{1}{|c|}{$\mathrm{N}$} & Minimum & Maximum & Mean & Std. Deviation \\
\hline Nilai Perusahaan & 10 & 1,36 & 8,46 & 4,0780 & 2,40188 \\
Kebijakan Hutang & 10 &, 38 & 1.10 &, 6040 &, 19557 \\
Keputusan Investasi & 10 & 1 & 51 & 23,9080 & 14,93725 \\
Valid N (listwise) & 10 & & & & \\
\hline
\end{tabular}

Sumber : data diolah (SPSS ver. 21.0)

Berdasarkan tabel uji statistik deskriptif diatas menunjukan bahwa pada penelitian ini nilai perusahaan memiliki nilai maksimum sebesar 8.46 dan nilai minimum sebesar 1.36 dengan nilai rata - rata yaitu sebesar 4.0780 dan nilai standar deviasi yaitu sebesar 2.40188.

Sedangkan untuk kebijakan hutang memiliki nilai maksimum sebesar 1.10 dan nilai minimum sebesar 0.38 dengan nilai rata - rata yaitu sebesar 0.6040 dan nilai standar deviasi yaitu sebesar 0.19557 .

Kemudian untuk keputusan investasi memiliki nilai maksimum sebesar 51 dan nilai minimum sebesar 6.44 dengan nilai rata - rata yaitu sebesar 23.9080 dan nilai standar deviasi yaitu sebesar 14.93725 .

\section{Uji Asumsi Klasik \\ Uji Normalitas}

Hasil pengujian normalitas data pada variabel kebijakan hutang, keputusan investasi terhadap nilai perusahaan di peroleh hasil :

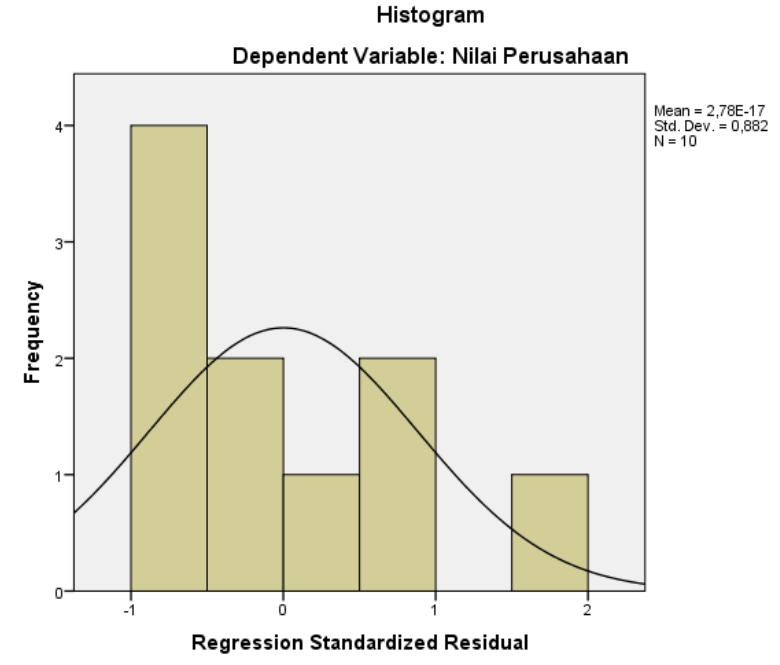

Gambar 2. Kurva Uji Normalitas

Analisis lebih lanjut dengan menggunakan Normal Probability Plot Of Regression Standardized Residual dapat dilihat pada gambar di bawah ini di peroleh hasil sebagai berikut : 


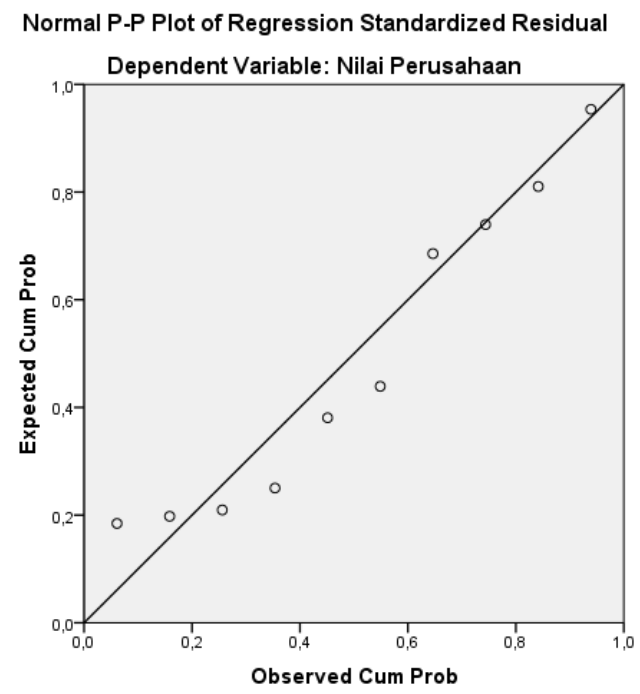

Gambar 3. Hasil Uji Normalitas

Dari hasil uji normalitas yang ada, dengan melihat tampilan grafik normal plot dapat disimpulkan bahwa grafik normal plot terlihat titik - titik menyebar disekitar garis diagonal, serta mengikuti arah garis diagonal. Dapat dikatakan bahwa distribusi data model regresi ini adalah normal.

Adapun untuk menguji kebenaran data apakah normal atau tidak, maka dalam uji normalitas ini dilakukan dengan menggunakan uji Kolmogorov-Simirnov Test. Uji tersebut dapat dilihat pada tabel berikut :

Tabel 3. Hasil Uji Kolmogorov-Simirnov Test One-Sample Kolmogorov-Smirnov Test

\begin{tabular}{|ll|r|}
\hline & & $\begin{array}{r}\text { Unstandardiz } \\
\text { ed Residual }\end{array}$ \\
\hline $\mathrm{N}$ & Mean & 10 \\
Normal Parameters & a,b & Std. Deviation \\
& Absolute & 1,80761797 \\
Most Extreme & Positive &, 178 \\
Differences & Negative &, 178 \\
Kolmogorov-Smirnov Z & &,- 154 \\
Asymp. Sig. (2-tailed) & &, 562 \\
\hline
\end{tabular}

a. Test distribution is Normal.

b. Calculated from data.

Sumber : data diolah (SPSS ver. 21.0)

Berdasarkan tabel diatas dapat kita lihat bahwa nilai Asymp.Sig.(2-tiled) sebesar 0.911. pada umumnya syarat lolos uji normalitas adalah nilai Asymp.Sig.(2-tiled) lebih besar dari 0.05. berdasarkan hasil perhitungan yang ada, data dalam penelitian ini dikatakan normal karena 0.911 lebih besar dari 0.05 sehingga bisa dikatakan data yang ada lolos dalam uji normalitas tersebut.

\section{Uji Multikolinearitas}

Uji ada tidaknya multikolinieritas dengan melihat Tolerence dan VIF. Semakin kecil nilai tolerance dan semakin besar nilai VIF maka semakin mendekati masalah multikolineritas. Jika tolerance $>0,1$ dan $\mathrm{VIF}<10$. Berikut dapat dilihat dari tabel di bawah ini : 
Tabel 4. Hasil Uji Multikolinearitas

Coefficients $^{\mathbf{a}}$

\begin{tabular}{|c|c|c|c|c|c|c|c|}
\hline \multirow{2}{*}{ Model } & \multicolumn{2}{|c|}{$\begin{array}{l}\text { Unstandardized } \\
\text { Coefficients }\end{array}$} & \multirow{2}{*}{\begin{tabular}{|c|}
$\begin{array}{c}\text { Standardized } \\
\text { Coefficients }\end{array}$ \\
Beta \\
\end{tabular}} & \multirow{2}{*}{$\mathrm{t}$} & \multirow{2}{*}{ Sig. } & \multicolumn{2}{|c|}{$\begin{array}{l}\text { Collinearity } \\
\text { Statistics }\end{array}$} \\
\hline & B & $\begin{array}{l}\text { Std. } \\
\text { Error }\end{array}$ & & & & Tolerance & VIF \\
\hline (Constant) & 7,867 & 2,912 & & 2,702 & ,031 & & \\
\hline 1 Kebijakan Hutang & $-7,258$ & 3,702 &,- 591 & $-1,960$ & ,091 & 890 & 1,123 \\
\hline Keputusan Investasi & 025 & 048 & 155 & ,513 & 624 & 890 & 1,123 \\
\hline
\end{tabular}

a. Dependent Variable: Nilai Perusahaan

Sumber : data diolah (SPSS ver. 21.0)

Dari hasil uji multikolinieritas menunjukkan bahwa nilai tolerance dan VIF pada variabel independen tersebut menunjukkan bahwa tidak terjadi multikolinearitas karena nilai tolerance pada variabel independen $0.890>0.10$ dan nilai VIF $1.123<10$. Sehingga dapat disimpulkan bahwa model regresi pada penelitian ini tidak terjadi gangguan multikolinieritas.

\section{Uji Heterokedastisitas}

Model regresi yang baik adalah tidak adanya masalah heteroskedastisitas. Hasil Uji Heteroskedastisitas dapat di lihat pada gambar berikut ini :

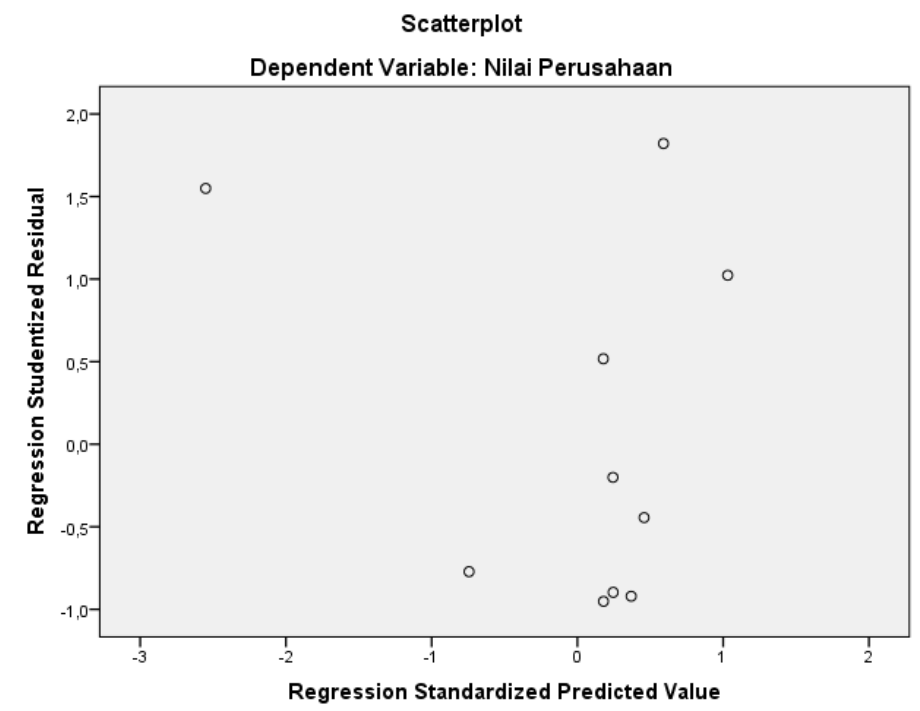

Gambar 4. Hasil Heteroskedastisitas

Deteksi ada atau tidaknya heteroskedastisitas dapat dilakukan dengan melihat ada tidaknya pola tertentu pada grafik scatteplot antara SRESID dan ZPRED. Pada gambar diatas, terlihat bahwa titik - titik yang ada telah menyebar di atas dan dibawah angka nol pada sumbu Y dan tidak terlihat pola tertentu. Dengan demikian dalam model ini tidak terjadi gejala heteroskedastisitas. Sehingga model regresi layak dipakai dalam penelitian karena telah memenuhi asumsi-asumsi dalam Uji Heterokedastisitas.

Adapun untuk menguji kebenaran data apakah terjadi heteroskedatisitas atau tidak, maka dalam uji heteroskedastisitas ini dilakukan juga dengan menggunakan uji glejser. Uji tersebut dapat dilihat pada tabel berikut : 
Tabel 5. Hasil Uji Heteroskedastisitas Metode Uji Glejser

Coefficients $^{\mathrm{a}}$

\begin{tabular}{|rl|r|r|r|r|r|}
\hline \multirow{2}{*}{ Model } & \multicolumn{2}{|c|}{$\begin{array}{c}\text { Unstandardized } \\
\text { Coefficients }\end{array}$} & $\begin{array}{c}\text { Standardized } \\
\text { Coefficients }\end{array}$ & \multirow{2}{*}{$\mathrm{t}$} & \multirow{2}{*}{ Sig. } \\
\cline { 2 - 4 } & \multicolumn{1}{|c|}{$\mathrm{B}$} & Std. Error & \multicolumn{1}{c|}{ Beta } & & \\
\hline \multirow{2}{*}{1 (Constant) } & 3,560 & 1,096 & & 3,248 &, 014 \\
& Kebijakan Hutang & $-2,144$ & 1,394 &,- 491 & $-1,538$ &, 168 \\
& Keputusan Investasi &,- 032 &, 018 &,- 551 & $-1,728$ &, 128 \\
\hline
\end{tabular}

a. Dependent Variable: Abs_RES

Sumber : data diolah (SPSS ver. 21.0)

Persyaratan lolos uji glejser adalah nilai signifikan lebih besar dari 0.05 . berdasarkan tabel diatas kita dapat melihat bahwa kebijakan hutang memiliki nilai signifikansi sebesar 0.168 dan keputusan investasi memiliki nilai signifikansi sebesar 0.128. Berdasarkan hasil perhitungan tersebut maka data dalam penelitian ini dikatakan tidak terjadi heteroskedastisitas karena nilai signifikansi lebih besar dari 0.05 sehingga bisa dikatakan data yang ada lolos dalam uji glejser tersebut.

Uji Autokorelasi

Model regresi yang baik mensyaratkan tidak adanya masalah autokorelasi, untuk mendeteksi ada tidaknya autokorelasi dengan melakukan uji Durbin-Watson.

Tabel 6. Hasil Uji Autokorelasi Metode Uji Durbin - Watson

\begin{tabular}{|l|r|r|r|r|c|}
\hline Model & $\mathrm{R}$ & R Square & $\begin{array}{c}\text { Adjusted R } \\
\text { Square }\end{array}$ & $\begin{array}{c}\text { Std. Error of } \\
\text { the Estimate }\end{array}$ & $\begin{array}{c}\text { Durbin- } \\
\text { Watson }\end{array}$ \\
\hline 1 &, $658^{\mathrm{a}}$ &, 434 &, 272 & 2,04965 & 2,230 \\
\hline
\end{tabular}

a. Predictors: (Constant), Keputusan Investasi, Kebijakan Hutang

b. Dependent Variable: Nilai Perusahaan

Sumber : data diolah (SPSS ver. 21.0)

Nilai Durbin - Watson sebesar 2.230 lebih besar dari batas atas (du) yakni 1.6413 dan kurang dari (4-du) 4-1.6413 atau DW = $2.230>1.6413$, DW $=2.230<(4-1.6413)$, maka sebagaimana dasar pengambilan keputusan dalam uji durbin watson diatas, dapat disimpulkan bahwa tidak terdapat masalah atau gejala autokorelasi. Dengan demikian maka analisis regresi linear berganda untuk uji hipotesis penelitian dapat dilanjutkan.

\section{Analisis Kuantitatif}

\section{Regresi Linier Sederhana}

Tabel 7. Hasil Uji Regresi Linier Sederhana Variabel Kebijakan Hutang ( $\left.\mathbf{X}_{1}\right)$ Terhadap Nilai Perusahaan (Y) Coefficients ${ }^{\mathrm{a}}$

\begin{tabular}{|cl|r|r|r|r|r|}
\hline \multirow{2}{*}{ Model } & \multicolumn{2}{|c|}{$\begin{array}{c}\text { Unstandardized } \\
\text { Coefficients }\end{array}$} & $\begin{array}{c}\text { Standardized } \\
\text { Coefficients }\end{array}$ & \multirow{2}{*}{ Sig. } \\
\cline { 2 - 4 } & \multicolumn{1}{|c|}{$\mathrm{B}$} & Std. Error & \multicolumn{1}{c|}{ Beta } & & \\
\hline \multirow{2}{*}{1} & (Constant) & 8,841 & 2,103 & & 4,204 &, 003 \\
& Kebijakan Hutang & $-7,886$ & 3,329 &,- 642 & $-2,369$ &, 045 \\
\hline
\end{tabular}

a. Dependent Variable: Nilai Perusahaan

Sumber : data diolah (SPSS ver. 21.0) 
Dari hasil diatas menjelaskan bahwa :

1) Nilai konstanta 8.841 menunjukkan bahwa ketika Variabel Kebijakan Hutang $\left(\mathrm{X}_{1}\right)$ bernilai nol maka Nilai Perusahaan (Y) bernilai 8.841

2) Koefisien regresi Variabel Kebijakan Hutang $\left(X_{1}\right)$ sebesar -7.886, dengan nilai negatif mengandung arti bahwa kenaikan setiap $1 \%$ unit Kebijakan Hutang $\left(\mathrm{X}_{1}\right)$ maka Nilai Perusahaan (Y) akan mengalami penurunan.

Sehingga dapat disimpulkan bahwa hasil pengujian diatas yaitu Kebijakan Hutang $\left(\mathrm{X}_{1}\right)$ berpengaruh negatif terhadap Nilai Perusahaan (Y).

Tabel 8. Hasil Uji Regresi Linier Sederhana Variabel Keputusan Investasi $\left(\mathrm{X}_{2}\right)$ Terhadap Nilai Perusahaan (Y) Coefficients ${ }^{\mathbf{a}}$

\begin{tabular}{|c|c|c|c|c|c|}
\hline \multirow{2}{*}{ Model } & \multicolumn{2}{|c|}{$\begin{array}{c}\text { Unstandardized } \\
\text { Coefficients }\end{array}$} & $\begin{array}{l}\text { Standardized } \\
\text { Coefficients }\end{array}$ & \multirow[t]{2}{*}{$\mathrm{t}$} & \multirow[t]{2}{*}{ Sig. } \\
\hline & B & Std. Error & Beta & & \\
\hline (Constant) & 2,732 & 1,480 & & 1,846 & ,102 \\
\hline Keputusan Investasi & 056 & 053 & ,350 & 1,058 & 321 \\
\hline
\end{tabular}

a. Dependent Variable: Nilai Perusahaan

Sumber : data diolah (SPSS ver. 21.0)

Dari hasil diatas menjelaskan bahwa :

1) Nilai konstanta 2.732 menunjukkan bahwa ketika Variabel Keputusan Investasi $\left(X_{2}\right)$ bernilai nol maka Nilai Perusahaan (Y) bernilai 2.732

2) Koefisien regresi variabel Keputusan Investasi $\left(X_{2}\right)$ sebesar 0.056 , dengan nilai positif mengandung arti bahwa kenaikan setiap 1\% unit Keputusan Investasi $\left(\mathrm{X}_{2}\right)$ maka Nilai Perusahaan $(\mathrm{Y})$ akan mengalami kenaikan.

Sehingga dapat disimpulkan bahwa hasil pengujian diatas yaitu Keputusan Investasi $\left(\mathrm{X}_{2}\right)$ berpengaruh positif terhadap Nilai Perusahaan $(\mathrm{Y})$.

\section{Regresi Linier Berganda}

Tabel 9. Hasil Uji Regresi Linier Berganda Coefficients $^{\mathrm{a}}$

\begin{tabular}{|c|c|c|c|c|c|}
\hline \multirow{2}{*}{ Model } & \multicolumn{2}{|c|}{$\begin{array}{c}\text { Unstandardized } \\
\text { Coefficients }\end{array}$} & \multirow{2}{*}{$\begin{array}{c}\begin{array}{c}\text { Standardized } \\
\text { Coefficients }\end{array} \\
\text { Beta } \\
\end{array}$} & \multirow[t]{2}{*}{$\mathrm{t}$} & \multirow[t]{2}{*}{ Sig. } \\
\hline & $\mathrm{B}$ & Std. Error & & & \\
\hline (Constant) & 7,867 & 2,912 & & 2,702 & 031 \\
\hline 1 Kebijakan Hutang & $-7,258$ & 3,702 &,- 591 & $-1,960$ & 091 \\
\hline Keputusan Investasi & 025 & 048 & ,155 & ,513 & 624 \\
\hline
\end{tabular}

a. Dependent Variable: Nilai Perusahaan

Sumber : data diolah (SPSS ver. 21.0)

Dari tabel uji regresi linier berganda diatas maka diperoleh persamaan sebagai berikut: Nilai Perusahaan $=7.867-7.258 X_{1}+0.025 X_{2}$

Dari persamaan di atas maka dapat diinterprestasikan beberapa hal, antara lain :

a. Nilai konstanta persamaan adalah sebesar 7.867 artinya apabila semua variabel independen yaitu Kebijakan Hutang dan Keputusan Investasi bernilai nol, maka Nilai Perusahaan bernilai 7,867.

b. Koefisien regresi variabel $\mathrm{X}_{1}$ kebijakan hutang sebesar -7.258 , artinya kebijakan hutang memiliki pengaruh negatif atau berlawanan arah terhadap Nilai Perusahaan, dimana untuk menaikan Nilai Perusahaan maka kebijakan hutang harus di turunkan. 
c. Koefisien regresi variabel $\mathrm{X}_{2}$ Keputusan Investasi sebesar 0,025, artinya Keputusan Investasi memiliki pengaruh positif atau searah terhadap Nilai Perusahaan, dimana untuk menaikan Nilai Perusahaan maka nilai Keputusan Investasi harus dinaikan.

\section{Uji Statistik \\ Uji-t (Uji Parsial)}

Tabel 10. Hasil Uji Stastistik Uji-t

Coefficients $^{\mathbf{a}}$

\begin{tabular}{|c|c|c|c|c|c|c|}
\hline & \multirow[t]{2}{*}{ Model } & \multicolumn{2}{|c|}{$\begin{array}{c}\text { Unstandardized } \\
\text { Coefficients }\end{array}$} & $\begin{array}{c}\text { Standardized } \\
\text { Coefficients }\end{array}$ & \multirow[t]{2}{*}{$\mathrm{t}$} & \multirow[t]{2}{*}{ Sig. } \\
\hline & & B & Std. Error & Beta & & \\
\hline \multirow{3}{*}{1} & (Constant) & 7,867 & 2,912 & & 2,702 & 031 \\
\hline & Kebijakan Hutang & $-7,258$ & 3,702 &,- 591 & $-1,960$ & 091 \\
\hline & Keputusan Investasi & 025 & ,048 & ,155 & ,513 & 624 \\
\hline
\end{tabular}

a. Dependent Variable: Nilai Perusahaan

Sumber : data diolah (SPSS ver. 21.0)

Berdasarkan tabel di atas diketahui nilai signifikan untuk variabel $\mathrm{X}_{1}$ sebesar 0,091 ini menunjukkan bahwa nilai signifikasi lebih besar dari 0,05 atau $0.091>0,05$ sehingga $\mathrm{H}_{0}$ diterima dan $\mathrm{H}_{1}$ ditolak yang menunjukkan bahwa variabel kebijakan hutang tidak berpengaruh terhadap Nilai perusahaan.

Untuk $t_{\text {tabel }}$ dapat dicari pada tabel statistik pada signifikasi $0,05 / 2=0,025$ (uji 2 sisi) dengan $\mathrm{df}=\mathrm{n}-\mathrm{k}-1$ atau 10-2-1 = 7 ( $\mathrm{k}$ adalah jumlah variabel independen) di dapat $t_{\text {tabel }}$ 2,36462. Dalam pengujian ini variabel kebijakan hutang diperoleh hasil -1.960. Artinya nilai $\mathrm{t}_{\text {hitung }}<\mathrm{t}_{\text {tabel }}$ yaitu $-1.960<2.365$, hal ini menunjukkan bahwa kebijakan hutang tidak berpengaruh secara signifikan terhadap nilai perusahaan.

Nilai signifikan untuk variabel $\mathrm{X}_{2}$ lebih besar dari 0,05 atau $0.624>0,05$ sehingga $\mathrm{H}_{0}$ diterima dan $\mathrm{H}_{2}$ ditolak yang menunjukkan bahwa variabel keputusan investasi tidak berpengaruh secara signifikan terhadap Nilai perusahaan.

Keputusan investasi diperoleh hasil $t_{\text {hitung }}$ sebesar 0.513 . Artinya nilai $t_{\text {hitung }}<t_{\text {tabel }}$ yaitu $0.513<2.365$ berarti bahwa keputusan investasi tidak berpengaruh secara signifikan terhadap nilai perusahaan.

\section{Uji-F}

Tabel 11. Hasil Uji Stastistik Uji-F ANOVA

\begin{tabular}{|c|c|c|c|c|c|c|}
\hline & Model & Sum of Squares & Df & $\begin{array}{c}\text { Mean } \\
\text { Square }\end{array}$ & $\mathrm{F}$ & Sig. \\
\hline \multirow{3}{*}{1} & Regression & 28,062 & 2 & 14,031 & 4,834 &, $048^{b}$ \\
\hline & Residual & 20,317 & 7 & 2,902 & & \\
\hline & Total & 48,378 & 9 & & & \\
\hline
\end{tabular}

a. Dependent Variable: Nilai Perusahaan

b. Predictors: (Constant), Keputusan Investasi, Kebijakan Hutang

Sumber : data diolah (SPSS ver. 21.0)

Dari uji ANOVA (Analysis of Varians) atau uji $\mathrm{F}$, menunjukkan bahwa $\mathrm{F}_{\text {hitung }}$ sebesar 4.834 dengan nilai signifikansi sebesar 0.048 berdasarkan $F_{\text {tabel }}$ yang ada, jumlah sampel $(n)=$ 10. Jumlah variabel (K-2). Taraf signifikansi $=0.05$ atau $5 \%$ maka didapatkan nilai tabel sebesar 4.46. Sehingga dapat diketahui bahwa $\mathrm{F}_{\text {hitung }} 4.834>\mathrm{F}_{\text {tabel }} 4,66$ maka dengan demikian $\mathrm{H}_{3}$ diterima sehingga kesimpulannya kebijakan hutang dan keputusan investasi berpengaruh secara signifikan terhadap nilai perusahaan. 


\section{Koefisien Determinasi $\left(\mathbf{R}^{2}\right)$}

\section{Tabel 12. Hasil Uji Koefisien Determinasi $\left(\mathbf{R}^{2}\right)$}

Model Summary

\begin{tabular}{|l|c|r|r|r|}
\hline Model & $\mathrm{R}$ & $\mathrm{R}$ Square & $\begin{array}{c}\text { Adjusted R } \\
\text { Square }\end{array}$ & $\begin{array}{c}\text { Std. Error of the } \\
\text { Estimate }\end{array}$ \\
\hline 1 &, $658^{\mathrm{a}}$ &, 434 &, 272 & 2,04965 \\
\hline
\end{tabular}
a. Predictors: (Constant), Keputusan Investasi, Kebijakan Hutang
Sumber : data diolah (SPSS ver. 21.0)

Dari tabel diatas dapat diketahui bahwa koefisien determinasi yang disesuaikan 0.272 atau $27.2 \%$. Ini berarti hanya $27.2 \%$ dari variabel dependen yaitu nilai perusahaan dapat dijelaskan atau dipengaruhi oleh variabel independen dalam penelitian ini yaitu kebijakan hutang dan keputusan investasi. Sedangkan sisanya sebesar $73.8 \%$ dijelaskan oleh variabel lain yang tidak diteliti dalam penelitian ini.

\section{Pembahasan Penelitian}

1. Pengaruh Kebijakan Hutang Terhadap Nilai Perusahaan

Dari hasil penelitian yang dilakukan oleh penulis, secara parsial diketahui signifikan variabel $\mathrm{X}_{1}$ sebesar 0.091, ini menunjukkan bahwa nilai signifikasi lebih besar dari 0,05 atau 0,091 > 0,05 sehingga dapat di disimpulkan jika nilai signifikasi sig $>0,05$ maka $\mathrm{H}_{1}$ di tolak, yang menunjukkan bahwa kebijakan hutang tidak berpengaruh secara signifikan terhadap nilai perusahaan. Hasil ini sejalan dengan jurnal penelitian yang dilakukan oleh Gema Fajar Ramadhan, Firtia Husnatarina, dkk yang menunjukkan bahwa kebijakan hutang tidak berpengaruh secara signifikan terhadap nilai perusahaan.

2. Pengaruh Keputusan Investasi Terhadap Nilai Perusahaan

Dari hasil penelitian yang dilakukan oleh penulis, secara parsial diketahui signifikan variabel $\mathrm{X}_{2}$ sebesar 0.624 , ini menunjukkan bahwa nilai signifikasi lebih besar dari 0,05 atau 0,624 > 0,05 sehingga dapat di disimpulkan jika nilai signifikasi sig $>0,05$ maka $\mathrm{H}_{2} \mathrm{di}$ tolak. Ini berarti menunjukan bahwa tidak terdapat pengaruh signifikan antara keputusan investasi terhadap nilai perusahaan. Hasil ini sejalan dengan penelitian yang dilakukan oleh Nila Ustiani yang menunjukkan bahwa tidak ada pengaruh yang signifikan antara keputusan investasi terhadap nilai perusahaan.

3. Pengaruh Kebijakan Hutang dan Keputusan Investasi Terhadap Nilai Perusahaan

Dari penelitian yang dilakukan oleh penulis, menunjukan bahwa kebijakan hutang dan keputusan investasi berpengaruh terhadap nilai perusahaan, hal ini berdasarkan nilai $\mathrm{F}_{\text {hitung }}<$ nilai $\mathrm{F}_{\text {tabel }}$ yaitu sebesar $4.834>4.66$ atau $\mathrm{F}_{\text {hitung }} 4.834>\mathrm{F}_{\text {tabel }} 4,66$. lalu kemudian untuk sig. $<0.05$ yaitu $0.048>0.05$ maka dengan demikian $\mathrm{H}_{3}$ diterima. Jadi dapat disimpulkan bahwa kebijakan hutang dan keputusan investasi berpengaruh terhadap nilai perusahaan. Hasil ini sejalan dengan jurnal penelitian oleh Hari Purnama yang menunjukkan bahwa ada pengaruh yang signifikan antara kebijakan hutang dan keputusan investasi terhadap nilai perusahaan.

\section{Kesimpulan}

1) Berdasarkan tabel hasil uji analisis regresi berganda dapat diketahui jika variabel kebijakan hutang tidak berpengaruh secara signifikan terhadap nilai perusahaan. Hal ini menandakan bahwa perusahaan belum mampu secara maksimal mengelola dan mengembangkan kebijakan hutangnya dalam meningkatkan Nilai Perusahaannya. 
2) Berdasarkan tabel hasil uji analisis regresi berganda dapat diketahui jika variabel keputusan investasi tidak berpengaruh secara signifikan terhadap nilai perusahaan. Hasil ini menandakan bahwa perusahaan belum mampu secara maksimal mengelola dan mengembangkan keputusan investasi dalam meningkatkan Nilai Perusahaannya.

3) Berdasarkan tabel hasil uji simultan, menunjukkan bahwa kebijakan hutang dan keputusan investasi berpengaruh secara signifikan terhadap nilai perusahaan. Hal ini berarti bahwa kedua variabel tersebut memiliki peran penting dalam meningkatkan Nilai Perusahaan PT. Arwana Citramulia.

\section{Daftar Pustaka}

Angela, L. M. Husnatarina, F \& Ramadhan, G. F, (2017). Pengaruh Kebijakan Hutang dan Kebijakan Dividen Terhadap Nilai Perusahaan Kelompok LQ45 yang Terdaftar di Bursa Efek Indonesia Tahun 2012-2016. Jurnal RAK (Riset Akuntansi Keuangan, 3(1), 1-9.

Dahela. (2018). Pengaruh Tax Planning, Kebijakan Hutang dan Kebijakan Dividen Terhadap Nilai Perusahaan. Jurnal Ekonomi Universitas Pamulang, 4(2), 1-13.

Dewi, I.K. (2017). Valuasi Saham pada Perusahaan Tambang Batubara yang Terdaftar di Bursa Efek Indonesia dengan Menggunakan Metode Free Cash Flow to Equity dan Price Earning Ratio. Jurnal Eduka : Jurnal Pendidikan, Hukum, dan Bisnis. 2 (1)

Dewi, I.K., \& Solihin, D. (2020). PENGARUH CURRENT RATIO DAN NET PROFIT MARGIN TERHADAP HARGA SAHAM PADA PERUSAHAAN MAKANAN DAN MINUMAN YANG TERDAFTAR DI BURSA EFEK INDONESIA (BEI) PERIODE 2015-2018. JURNAL ILMIAH FEASIBLE: Bisnis, Kewirausahaan \& Koperasi 2 (2), 183-191.

Dewi, I.K. (2020). Penyuluhan Pemanfaatan Limbah Buah Menjadi Pupuk Cair Organik Untuk Memenuhi Kebutuhan Petani Buah Palawija dan Sayuran Dalam Meningkatkan Pendapatan Keluarga di Desa Karang Dadap Kecamatan Kalibagor, Banyumas-Jawa Tengah. Journal of Society Engagement. 1 (1), 65-76.

Dewi, I.K. (2020). Pemanfaatan Kain Perca sebagai aksesoris Motif Hiasan pada Pakaian dan Tas sebagai bentuk Peluang Usaha. Jurnal Lokabmas Kreatif. 1 (1), 1-6.

Dewi, I.K. (2020). Pengelolaan Hasil Pertanian dalam Meningkatkan Harga Jual pada Petani di Desa Cicalengka Kecamatan Pagedangan Kabupaten Tangerang-Banten. Jurnal Dedikasi PKM 1 (3)

Fahmi, I. (2014). Pengantar Manajemen Keuangan. Bandung: Alfabeta.

Firmansyah, A. M. (2018). Pengaruh Kebijakan Hutang, Kebijakan Dividen dan Beban Pajak Tangguhan terhadap Nilai Perusahaan. Jurnal Ekonomi Universitas Pamulang, 1-15.

Ghozali, I. (2016). Aplikasi Analisis Multivariete dengan Program IBM SPSS 23. Semarang: Badan Penerbit Universitas Diponegoro.

Kasmir. (2015). Analisis Laporan Keuangan. Jakarta: Rajawali Pers.

Mardiana, S. (2018). Analisis pengaruh Return On Asset, Pertumbuhan Laba dan Debt To Equity Ratio terhadap Return Saham dan dampaknya terhyadap Nilai Perusahaan. Jurnal Disrupsi Bisnis, 1(2), 1-19.

Mardiana, S. (2020). Optimalisasi Anggaran Keuangan di Masa Pandemi pada Desa Cicalengka Kabupaten Pegedangan Tangerang. Jurnal Dedikasi PKM, 1(3), 114-119.

Mardiana, S. (2020). Sosialisasi dan Penyuluhan Tentanng Pentingnya Menabung bagi Generasi Muda Khususnya Siswa Madrasah Tsanawiyah MTS Mathlaul Anwar Pamulang. . Jurnal Dedikasi PKM, 1(2), 79-86. 
Mardiana, S. (2020). Strategi Manajemen Keuangan untuk Optimalisasi Pengelolaan Income pada Karyawan Medis dan Non Medis RS. Medika BSD di Era Millenial. Jurnal Abdi Laksana, 1(2), 290-296.

Mardiana, S. (2020). Pengembangan Potensi Ekonomi Kewirausahaan Ibu Rumah Tangga dalamMeningkatkan Ekonomi Masyarakat Kelurahan Cempaka Putih Ciputat. Jurnal Lokabmas Kreatif, 1(1), 89-95.

Mardiana, S. (2020). Meningkatkan Minat dan Potensi Generasi MIlenial Khususnya SiswaSiswi SMK Darussalam untuk Memulai BIsnis Online dengan Sistem Dropship. Jurnal Dedikasi PKM, 1(2), 100-104.

Munawir. (2014). Analisa Laporan Keuangan. Yogyakarta: Liberty.

Ningsih, R (2018). Pengaruh Hutang Jangka Panjang, Hutang Jangka Pendek dan Modal Terhadap Biaya Modal dan Dampaknya terhadap Nilai Perusahaan. Jurnal Ekonomi Universitas Pamulang, 1-39.

Rosmawati, A. (2018). Pengaruh Kebijakan Dividen, Kebijakan Hutang dan Tax Planning Terhadap Nilai Perusahaan. Jurnal Ekonomi Universitas Pamulang, 4(2), 1-13.

Prayitno, D. (2012). Cara Kilat Belajar Analisis Data dengan SPSS 20. Edisi Kesatu. Yogyakarta: ANDI.

Purnama, H. (2015). Pengaruh Profitabilitas, Kebijakan Hutang, Kebijakan Deviden, dan Keputusan Investasi Terhadap Nilai Perusahaan (Studi Kasus Perusahaan Manufaktur yang Go Publik di Bursa Efek Indonesia) Periode 2010 - 2014. Jurnal Akuntansi, 4(1), 111.

Ramadhan, S (2018). Pengaruh Kebijakan Hutang, Ukuran Perusahaan dan Tax Avoidance terhadap Nilai Perusahaan. Jurnal Ekonomi Universitas Pamulang, 1-17.

Rokhmawati, A. (2016). Manajemen Keuangan. Yogyakarta: Deepublish.

Santoso, S. (2015). Buku Latihan SPSS Parmetrik. Jakarta: PT. Alexa Computindo.

Sartono, R. A. (2015). Manajemen Keuangan Teori dan Aplikasi. Yogyakarta: BPFE.

Solihin, D. (2019). Pengaruh Current Ratio Dan Debt To Equity Ratio Terhadap Return On Asset (ROA) Pada PT Kalbe Farma. Tbk, KREATIF: Jurnal Ilmiah Prodi Manajemen Universitas Pamulang 7 (1).

Sugiyono. (2015). Metode Penelitian Pendidikan Pendekatan Kuantitatif, Kualitatif dan R\&D. Bandung: Alfabeta.

Sugiyono. (2017). Metode Penelitian Kombinasi (Mixed Methods). Cet. Ke-8. Bandung: Alfabeta.

Usman, S. (2017). Perencanaan Dalam Keuangan Perusahaan. Yogyakarta: Deepublish.

Ustiani, N. (2014). Pengaruh Struktur Modal, Kepemilikan Manajerial, Keputusan Investasi, Kebijakan Dividen, Keputusan Pendanaan dan Profitabilitas Terhadap Nilai Perusahaan. Jurnal Ekonomi Universitas Pandanaran Semarang, 4(2), 1-20.

Wijaya, D. (2017). Manajemen Keuangan Konsep dan Penerapannya. Jakarta: PT. Grasindo.

Yuniarti, V. R. (2015). Perilaku Konsumen Teori dan Praktik. Bandung: Pustaka Setia.

www.idxfinancials.com

www.arwanacitra.com 